\title{
Structural Equation Modeling of E-Service Recovery Satisfaction and Customer Retention in the Airline Industry in Malaysia
}

\author{
Rafah A. Al-Jader ${ }^{1} \&$ Ilham Sentosa ${ }^{2}$ \\ ${ }^{1}$ City University College for Science and Technology, Malaysia \\ ${ }^{2}$ University Kuala Lumpur, Malaysia \\ Correspondence: Rafah Al-Jader, City University College for Science and Technology, Kuala Lumpur, Malaysia. \\ E-mail: rafah.aljader@rocketmail.com
}

Received: May 15, 2015 Accepted: June 4, 2015 Online Published: July 30, 2015

doi:10.5539/ijms.v7n4p105 URL: http://dx.doi.org/10.5539/ijms.v7n4p105

\begin{abstract}
In the age of the internet, customer retention has become a crucial element in firms' survival. Losing customers to competitors in the e-context is a constant threat, as the potential for this loss is 'only a click away'. The current study suggests two new constructs, accumulative trust and digital commitment as customer determinants appropriate for the online context. This study aims to investigate the effect of three customer determinants (accumulative trust, customer perception of feedback and digital commitment) on customer retention, focusing on the role of e-service recovery satisfaction as a mediator in these relationships. The investigation is in the context of the Malaysian Airline industry in general. Quantitative methodology was adopted using a self-administered questionnaire as the tool for data collection. The unit of analysis was Malaysian passengers who travel with different local airlines and who faced service failures. Structural equation modelling (SEM) was employed to analyse the data. The findings confirmed that e-service recovery satisfaction has a mediating influence on the relationships between accumulative trust and digital commitment and customer retention.
\end{abstract}

Keywords: accumulative trust, customer perception of feedback, digital commitment, e-service recovery satisfaction, customer retention

\section{Introduction}

The internet has become an indispensable tool to business and individuals in daily life. The number of internet users is continually increasing, reaching 2,802,478,934 users worldwide according to the latest data (Internet World Stats, 2014). The growth rate from 2000 to 2014 was 676.3 per cent. Asia contributes 45.1 per cent of the worldwide internet usage, which is equivalent to 1,265,143,702 internet users (Internet World Stats, 2014). These figures demonstrate that the internet has become an incredibly valuable tool, not only for business, but also for consumers, who enjoy easy access to companies' websites. Such websites were designed to demonstrate a variety of products and services facilitating the comparison of models, prices and quality with a click of a mouse (Ogungbure, 2009). Purchasing goods and services through the internet is a phenomenon that has been growing during the past two decades, and it will continue to grow (Internet World Stats, 2014). Researchers have noted that e-commerce has provided varied opportunities, but has also added new challenges (Shankar et al., 2003; Zhou \& Amin, 2014). This is because, with the advent of the internet era, the world has become like a wide market, where all types of goods and services are displayed, and customers can select providers and might switch to competitors with a click of a mouse. Loosing consumers is thus of great concern for businesses (Shankar et al., 2003). In addition, it is argued that, particularly in the service sector, gaining new customers bears higher costs than retaining existing customers (Ennew et al., 2015). Due to rapid technological developments, consumers have gained great purchasing power that resulted in changes to their behaviour and thinking patterns (De Mooij, 2010; Hsieh \& Tsao, 2014). This situation has heightened competition among providers. Companies and providers focus their efforts on improving their service quality to compete with other rivals. However, service failure is unavoidable. When a failure in service delivery occurs, providers should exert every effort to eliminate the negative effects of the service encounter. Providers can utilise service-recovery strategies that aim at minimising the negative effects of service failure and turning a dissatisfied customer into a satisfied customer (Tsai et al., 2014). In the current competitive business environment, the crucial element for companies' survival and their growth maintenance is retaining existing customers (Adebiyi \& Adeola, 2014). As such, it is essential 
that businesses are able to implement successful service-recovery strategies to retain their existing customers by converting customers who have had a negative service experience into satisfied and loyal customers (McCollough, 2009; St-James \& Taylor, 2004). The current study presents a theoretical framework that demonstrates the relationships among the five variables: accumulative trust, customers' perception of feedback, digital commitment, e-service recovery satisfaction and customer retention.

\section{Literature Review and Hypotheses}

Sousa and Voss (2009) noted that because service industries are witnessing escalating competition, researchers and businesses have paid more attention to service-recovery strategies. Even when service providers do their best to provide the best service possible and prevent any service failure, the possibility of such failure always exists. As such, the provider should always have the right approaches to manage such failures and recover customers (Shaw \& Craighead, 2003). If a customer encounters a negative service experience that is followed by poor service recovery, it affects negatively the provider-customer relationship and can lead quite easily and quickly to losing the customer (Edvardsson et al., 2011). However, if a well-designed recovery is offered to the customer, it can lead to transforming the dissatisfied customer into a satisfied and even loyal customer, thereby eliminating the negative effects of service failure (Arokiasamy, 2014). Accordingly, providers who have the ability to react to a service failure by offering successful service recovery will succeed in retaining their share of customers and consequently their market share (Eisingerich et al., 2014). Studies have demonstrated that retaining existing customers results in cost reduction and maintains and secures revenues and profits. Studies have also revealed that the cost of gaining one customer is five times greater than the cost of retaining an existing customer (Gupta et al., 2004; Kotler \& Keller, 2006). In addition, Kerin et al. (2009) demonstrated that retaining customers affects profits at a higher rate than does attracting new customers. As such, and according to previous research, implementing successful service-recovery strategies positively influences businesses' revenues and therefore profits. According to Bataineh et al. (2015), commitment and satisfaction have a strong impact on customer retention. The current study highlights the role of realising e-service recovery satisfaction in achieving customer retention. E-service recovery is characterised as a fast, accurate and effective means that providers can apply to absorb the negative effects of service failure. Reviewing the literature revealed gaps, which this study has sought to address. First; through intensive analysis of the literature, the study selected four existing terms that have been used mostly in relation to customer retention and present them as new customer determinants/factors for e-context: 'e-trust' and 'prior experience' were merged to produce the new construct: accumulative trust; 'e-loyalty' and 'digital awareness' were merged to produce the new construct: digital commitment. Second; the study investigated the relationships between customer determinants; accumulative trust, customers' perception of feedback and digital commitment, and customer retention and whether these relationships are direct or indirect. Third: the study examined the relationship between customer retention and e-service recovery satisfaction, and whether implementing effective e-service recovery can generate satisfaction that can lead to customer retention. The study also investigated the role of e-service recovery satisfaction as a mediator in the relationships between customer determinants and customer retention. The conceptualising of the new constructs will be detailed in the following sections.

To support the study's hypothesis, three theories were utilised. First, the Expectancy Disconfirmation Theory (EDT) (Oliver, 1980), which posits that once perceived performance and expectations occur together, it leads to post-purchase satisfaction. This effect is mediated by the positive or negative disconfirmation of performance expectations. The disconfirmation paradigm explains the comparison between the expected and the actual delivered performance to decide whether customer's expectations were met (Severt, 2002). This theory provides the support and basis for designing this study's hypotheses, which aim to clarify the effects of e-service recovery satisfaction on consumer behaviour. The second theory is Technology Acceptance Model (TAM) (Davis, 1989), which was designed specifically to explain the determinants of the information-technology (IT) behaviour of the end user. The main three determinants of the theory (perceived ease of use, perceived usefulness and attitude towards using the system) have supported the creation of the two constructs of this study (accumulative trust and digital commitment) and the building of the conceptual framework in reference to consumer IT acceptance and usage. The study posits that both customers' digital awareness and customers' tendency to use IT results in increasing customer exposure to the internet almost on a daily basis. Such exposure leads to deepen customer's digital experience and creates customer e-trust and e-loyalty to the service provider. The third theory incorporated in the study is Fritz Heider's (1958) Attribution Theory. This theory demonstrates people's causal attributions and shows how customers comprehend and use the information provided by company websites to explain the reasons behind service failure (Zemke \& Connellan, 2001). Attribution Theory identifies that people's attributions differ depending on three main dimensions: controllability (the extent to which the provider 
was able to control the cause), stability (the probability that the cause will occur again in the future) and locus (whether the cause was internal or external). These three dimensions influence the extent of satisfaction with the e-service recovery offered by a business and the customer's decision to switch to another service provider. Moreover, customers can use the information offered by the provider to explain service failures in relation to the three factors to decide to whom to attribute the blame and whether to tell others about the failure (Manusov \& Spitzberg, 2008). Attribution Theory supported this study's conceptual framework, which posits that justifying the service failure will influence the level of e-service recovery satisfaction, as well as the customer's future loyalty, repurchase intention and retention decision. The following review illustrates the theoretical framework for the five variables incorporated in this study and the relevant hypothesis.

\subsection{Accumulative Trust}

Accumulative trust, the first customer determinant, can be defined as the trust generated through the continuance interactions between e-customer and e-provider in the e-context. This construct is developed by the current study, and is the result of merging two concepts that have been investigated by many scholars in the marketing literature: trust and prior experience. In the 'bricks-and-mortar market' literature (traditional market), it is suggested that trust affects the intention to repurchase from the same provider in the future (Jarvenpaa et al., 2000 cited in Chinomona \& Dubihlela, 2014). Eid (2011) defined trust as consumer's beliefs regarding the provider and the consumer's future intentions and behaviours. After the internet revolution, the term 'e-trust' was developed to refer to consumers' trust in the electronic markets (Ha \& Akamavi, 2009). Online trust is defined as 'the belief that the behaviour of an online vender is dependable' (Ha \& Akamavi, 2009, p. 96). Shukla (2014; Ha \& Akamavi, 2009) emphasised that e-trust is the key factor in establishing and maintaining the customer-provider relationship. Bart et al. (2005) stressed that consumers' online experience can be related positively to online trust. However, Ha and Akamavi (2009) noted that using particular websites continually would positively affect customers' e-trust and attitude towards those providers' websites. In addition, Kim and Prabhakar (2000) concluded that the degree of consumers' trust in using e-transactions would affect the adoption of internet banking. The continuation of e-purchasing can develop and maintain customers' experience, leading to a change in their perceptions of the e-context (Chen \& Dubinsky, 2003). Flavián and Guinalíu (2006) demonstrated that privacy and perceived security influence the level of customer trust in the internet environment. Kim et al. (2009) also emphasised that previous dealings and experiences with a provider helps customers to decide whether to switch to another provider. Studies have suggested that trust is a concept that is built over time, which means it is accumulative (Bart el al., 2005; Ha \& Akamavi, 2009). As such, to build trust, customers need to experience many transactions that will generate a positive relationship with the provider. Trust in the e-context is considered even more vital and crucial element than it is in the tradition environment, as direct interaction is not available. Literature strongly indicates that trust and prior experience are overlapping and integrated concepts. Building on the previous literature, this study suggested the new term 'accumulative trust' which indicates to the e-trust that is based on previous e-transactions and experiences with online context.

\subsubsection{Accumulative Trust and Customer Retention}

Previous studies have emphasised the mediating role of trustworthiness in the process of service recovery and customer retention (Kim \& Prabhakar, 2000; Liao \& Wu, 2009; Rachjaibun, 2007). Customers' previous experience will direct them in their decision to switch to another provider or continue with the same provider (Chang \& Chang, 2011). Holloway et al. (2005) stated that greater experience in online purchasing would positively moderate some of the 'attitudinal and behavioural outcomes' of service recovery because high post-recovery satisfaction can indicate to customers' repurchase intentions. As such, the effect of a service failure will be greater with customers that have little experience with online purchasing. According to TAM, the perception of usefulness and ease of use will encourage customers to engage in online transactions. Ha and Akamavi (2009) posited that using the internet for a long time affects (positively or negatively) consumers' e-trust in web providers. If the customer's previous experience and transaction history is positive, trust will be gradually generated and built and can result in customer retention (Ha \& Akamavi, 2009; Bart el al., 2005). Considering all the factors, the current study suggests that the concept of 'accumulative trust' can affect customer retention. As such, the following hypothesis was developed for the relationship between accumulative trust and customer retention:

H1a. Accumulative trust positively influences customer retention.

Scholars such as Parasuraman et al. (2005) and Boshoff (1997) have stated that failing to achieve customer recovery satisfaction can result in negative word-of-mouth, less customer confidence, extra costs of re-performing the service and customer defection. E-trust is a vital element in repurchase intentions and building 
customer loyalty: empirical studies have shown that e-trust is positively related to customer satisfaction and commitment (Chang \& Chang, 2011). Scholars have also noted that trust is an indispensable factor in performing a successful service recovery (Chang \& Chang, 2011). Customers who were exposed to a positive service-recovery experience tend to be forgiving and respond positively to the service recovery (Hess et al., 2003; Tax et al., 1998). In addition, Chen and Dubinsky (2003) and Craighead et al. (2004) have emphasised that previous experiences with the e-provider affected customers' accumulative trust. As such, this study developed the following hypothesis, which indicates the suggested mediating role of e-service recovery satisfaction on the relationship between customer retention and accumulative trust:

H1b. E-Service recovery satisfaction mediates the relationship between accumulative trust and customer retention.

\subsection{Customer Perception of Feedback}

The second customer determinant indicates how customers perceive a provider's feedback about a service failure. Broderick and Vachirapornpuk (2002) stated that evaluating a service should be related to quality standards. Supporting this view, Bitner et al. (1990) noted that when a service failure occurs, it indicates that the service did not meet the customer's expectations. Smith et al. (1999) also stated that such an incident is the result of not delivering a service that meets the customer's expectations. After a service failure, customer satisfaction and happiness will only be achieved if recovery measures exceed a customer's expectations (Berry \& Parasuraman, 2004). However, studies have emphasised that an effective, clear and fast response to a customer's requests will indicate the provider's efficiency in dealing with service encounters (Zeithaml et al., 2000). Customer perception of feedback was used as a variable with the aim of highlighting the idea of the customer's evaluation for the feedback given by the provider after service encounter. According to the Attribution Theory, feedback evaluation by customers is a critical issue because it determines whether the feedback has met customer's expectations about the service recovery that they feel they should receive. These factors influence the level of satisfaction with recovery. Supporting this view, Bijmolt et al. (2014) recent study concluded that consumers who faced service encounters and were satisfied with the recovery offered through internet channels, demonstrated greater intention to repurchase than customers who did not face any service failure or customers who faced a failure but did not file a complaint. Customer perception of feedback is a vital and essential variable affecting future purchase plans, as it demonstrates customers' evaluation of the feedback offered by the company (Al-Jader \& Sentosa, 2015b).

\subsubsection{Customer Perception of Feedback and Customer Retention}

The term 'feedback' indicates the responsiveness of the provider to a customer's complaint (Oliver 1997; Yen \& Lu 2008). Oliver (1997) demonstrated that when the business initiates a discussion with the dissatisfied customer with the aim of solving the failed service encounter, the business' initiative influences the customer's satisfaction level, and can maintain satisfaction, which can be upgraded to loyalty. In a study in the context of mobile retailing, Kau and Loh (2006) demonstrated that when customers receive efficient and effective feedback in response to their complaints, the satisfied customers demonstrated higher levels of satisfaction with the recovery than did the dissatisfied customers. This was manifested by higher levels of trust, loyalty and customer retention. However, Bailey (1994) demonstrated that if a dissatisfied customer did not receive adequate feedback or their problem was not addressed appropriately, the negative effect of the failed service encounter became greater and the customer could become a 'threat' to the business, as they might switch to another provider or spread negative word-of-mouth. Söderlund (1998) also emphasised that dissatisfied customers demonstrate a high tendency to spread negative feedback because they want to achieve some compensation for the negative service. The United States Office of Consumer Affairs indicated that a dissatisfied customer might inform nine other people about their negative experience (Appiah-Gyimah et al., 2011). This threat can be even greater given that thousands of consumers have access to a single piece of negative feedback from a dissatisfied customer. Online communication has provided consumers with increased power to affect other consumers' purchasing decisions and judgments (Mangold et al., 1999). Hence, providers should pay extra attention to the feedback and recovery process because they can absorb the negative feelings of the dissatisfied customers and therefore avert negative consequences for the business. This study developed the following hypothesis to demonstrate the relationship between customer perception of feedback and customer retention:

\section{H2a. Customers' perception of feedback positively influences customer retention.}

Previous research has emphasised that effective responsiveness describes a sharp and fast response to customers' complaints and the ability of the provider to provide immediate assistance in case of service failures (Zeithaml et al., 2000). According to Voss (2003), providing customers with feedback and a fast, efficient response are 
indicators of high-quality service. Yang and Jun (2002) acknowledged that when comparing physical or traditional service providers to e-retailers, there is a lack of real-time interaction with customers in the e-context. As such, evaluating providers' feedback by customers is a vital step in satisfying customers' needs and assessing their perceptions of 'what they should receive as an e-service recovery' (Al-Jader \& Sentosa, 2015a). Ogungbure (2009) emphasised that when high satisfaction with service recovery is achieved, it indicates that the provider's response to the service failure was efficient and more than merely satisfactory. Providing such service recovery means customers' perceptions of feedback can be positive and lead to customer retention (Ogungbure, 2009). Thus, this study developed the following hypothesis to explain the relationship between customer retention and customer perception of feedback when e-service recovery satisfaction acts as a mediating factor.

H2b. E-service recovery satisfaction mediates the relationship between the customer's perception of feedback and customer retention.

\subsection{Digital Commitment}

Digital commitment, the third customer determinant, and the second new construct generated by this study. It can be defined as the process of building a knowledgeable, loyal and committed e-customer of an e-provider within the e-context. Generating this construct was based on in-depth analysis of the previous literature and TAM. Two important variables (e-loyalty and digital awareness) were integrated to produce 'digital commitment' as a construct that applies to the e-context. Many scholars have examined the concept of loyalty because it represents a central concept in the marketing literature (Oliver 1999; Zeithaml et al., 1996). Oliver (1997) noted that customer loyalty refers to the high level of a customer's commitment to repurchase their favourite product or service in the future. Such commitment results in repeat purchases of the same brand, despite there being a great deal of marketing and promotional influences that might lead to switching behaviour. Allagui and Temessek (2005) highlighted that the theoretical foundation for e-loyalty in the online context is quite similar to the theoretical foundation for loyalty in the traditional market. Kim et al. (2009) defined e-loyalty in the retail context as the customer's attitude towards their favoured online retailer that might lead to repurchase behaviour. Based on the review of loyalty in the literature, e-loyalty can be seen as representing an important factor for providers, particularly in the e-context, because switching to other providers bears no switching costs for the customer, as it requires a click of a mouse only (Ogungbure, 2009; Wang et al., 2014). Conversely, the concept of awareness is considered an important determinant for adopting a new product or service (Velmurugan \& Velmurugan, 2014). Hoffman and Novak (2009) argued that customers will gain more experience as they keep surfing business' websites, and this experience affects their attitudes, enhances their level of trust in the internet and maintains their digital knowledge. In addition, Holloway et al. (2005) emphasised that previous experience affects perceived risks, future purchase intentions and the decision to continue online purchasing. Here, it is worth mentioning the term 'flow', which indicates the positive feelings that web users experience as they surf the virtual space and forget about the physical world and its problems: "they tend to integrate themselves with keyboard, monitor, and cyberspace" (Csikszentmihalyi, 1975, p. 222 cited in Chen, 2006). During the flow experience, users will feel "cognitively efficient, motivated, and happy" (Moneta \& Csikszentmihalyi, 1996, p. 277 cited in Chen, 2006). Skadberg and Kimmel (2004 cited in Al-Jader \& Sentosa, 2015b) stressed that the 'flow experience' is a critical element that has significant positive effects for learning processes, leading to a changed attitude towards online channels. As such, e-loyalty and digital awareness are the result of the continuation of internet usage. Given that digital awareness can generate a higher degree of comfort with the e-context when performing online transactions, the current study merges the two concepts (e-loyalty and digital awareness) into one concept to generate the newly constructed term 'digital commitment', which indicates to customers' digital awareness and loyalty to the e-provider in the e-context. Digital commitment is

\subsubsection{Digital Commitment and Customer Retention}

This study emphasises that e-loyalty is an important and crucial factor in the e-context (Carter et al., 2014; Chiu et al., 2009; Forgas et al., 2012). Carter et al. (2014) expressed that a committed customer is a loyal customer, who demonstrates loyalty attitudes such as recommending the provider to others and repurchasing intentions (Bashar \& Wasiq, 2013; Komunda \& Osarenkhoe, 2012; Pizzutti \& Fernandes, 2010; Yang \& Peterson, 2004). Commitment results in an enhanced relationship with the provider and an expansion of the range of products purchased from the same provider (Bashar \& Wasiq, 2013; Eid, 2011). Digital commitment is a technology-based construct related to the new internet era. Its importance emerges from the fact that, within the e-context, switching providers does not bear any cost and is 'just a click away' (Shankar et al., 2003). Hence, digital commitment reflects technology awareness and adoption, interlaced with e-loyalty. Accordingly, digital commitment develops from the continuation of usage of the internet, which can create a higher degree of comfort with the online environment, leading the customer to perform more online transactions. The positive 
experiences with the same provider will gradually result into higher loyalty and commitment. As such, this study has generated the following hypothesis on the relationship between customer retention and digital commitment.

\section{H3a. Digital commitment positively influences customer retention.}

Chen and Dubinsky (2003) argued that in the e-context, continuation of purchasing could result in strengthening customers' experience in dealing with the various webpages in a manner that can change customer perceptions of the online context. This can affect future intentions for online transactions (Holloway et al., 2005). To realise digital commitment means consolidating the customer-provider relationship by expanding customers' purchasing behaviour to include the entire range of the same provider's services and products (Eid, 2011). The customer's level of knowledge of the e-context will determine the extent of their digital commitment (Hoffman \& Novak, 2009; Parasuraman et al., 2005). In addition, satisfaction with IT can be affected by the level of customer commitment to utilise digital information (Yang \& Peterson, 2004). Thus, customer e-loyalty is a critical element in the e-context because customers who are loyal and committed to a provider will generate more revenues and requires less investment in marketing promotions. Moreover, loyal customers will be more ready to forgive in the case of service failure, will be less price-sensitive and will engage in positive word-of-mouth advertising for the provider (Yang \& Peterson, 2004). This will help the business to maintain growth and increase profits and market share. As such, digital commitment can influence customer retention when satisfaction with e-service recovery is achieved. E-service recovery satisfaction can generate customers' positive feelings towards the e-context in general and the provider's website in particular (Cegarra-Navarro et al., 2014). The following hypothesis is connected to H3a, but incorporates e-service recovery satisfaction as a mediating factor in the relationship between digital commitment and customer retention.

H3b. E-service recovery satisfaction mediates the relationship between digital commitment and customer retention.

\subsection{Customer Retention}

According to Hoffman et al. (2003), customer retention refers to the approaches that providers adopt to secure and maintain relationships with existing customers for future transactions. The internet era has created fierce global competition among businesses, which focus on protecting their existing customer share because it is considered crucial and essential for competitive advantage. Tarokh and Ghahremanloo (2007) stated that the internet has established itself as a very important channel for building and expanding business, considering that IT developments have generated limitless and valuable opportunities for various entities to reach global markets. In the e-context, adopting IT applications serves as an interaction point between customers and providers. Understanding this interaction assists in understanding customers' behaviours through analysing their attitudes and behaviour patterns. As stated, if a successful service recovery is implemented after a failed service encounter, there exists the potential of not only satisfying the dissatisfied customer, but also retaining them, and if the service recovery is outstanding, the customer could become a delighted customer (St-James \& Taylor, 2004). In contrast, failing to implement service recovery and recover customers can lead to negative consequences such as negative word-of-mouth (or word-of-mouse) and losing customers, which result in a decrease in revenues and profits (Michel et al., 2009). Thus, both service failure and service recovery are recognised as critical opportunities for providers to satisfy and retain customers (Kian, 2011). Customer retention has enormous benefits for companies because it results in reducing marketing costs, given that existing customers require fewer marketing and promotional materials compared to new customers. Many studies have stated that attracting new customers has a higher cost than retaining existing customers (e.g., Kerin et al., 2009; Kotler et al., 2003). Reichheld and Sasser (1990) stated that some service entities could increase profits at a rate of 85 per cent if customer defection is decreased by five per cent. Another negative effect arising from customer dissatisfaction is the negative word-of-mouth: a dissatisfied customer is expected to inform nine people about the negative experience, affecting negatively the company's image (Rondeau, 1994).

\subsection{E-Service Recovery Satisfaction}

According to Oliver (1997), consumer satisfaction is created by many evaluations over many transactions; hence, it is termed 'long-term satisfaction' or 'overall satisfaction'. Boshoff (1997) noted that service recovery refers to the response of service providers to a failed service encounter. The importance of e-service recovery satisfaction emerges from its purpose which is to retain those dissatisfied customers who may be willing to change providers in case they witnessed a poor recovery experience (Ennew et al., 2015). Bashar and Wasiq (2013) emphasised that offering customers fair and fast service recovery is a crucial determinant in attaining both customer satisfaction and retention as the post-recovery phase. The most important benefit of customer retention is that it leads to cost reduction $(\mathrm{Ok}, 2004)$ and increased profits through greater customer loyalty. 


\subsubsection{E-Service Recovery Satisfaction and Customer Retention}

To achieve the goal of maintaining the customer-provider relationship and secure its continuation, the provider must ensure that effort was made to satisfy and please dissatisfied customers (Pizzutti \& Fernandes, 2010; Quin et al., 2012). The level of customer satisfaction is determined by the seriousness of the service failure (Ok, 2004). As such, if the provider initiates effective service recovery, it will lead to satisfied customers who may spread positive word-of-mouth and act as ambassadors for the provider (Ok, 2004; St-James \& Taylor, 2004). Stauss et al. (2001 cited in Hansemark \& Albinson, 2004) stated that customer retention has six characteristics: liking, commitment, identification, trust, repurchase intentions and recommendation. However, failing to recover a dissatisfied customer might lead to serious negative consequences such as customer defection and negative word-of-mouth or word-of-mouse, which will reflect a negative image for the business and decrease revenues and profits (Cambra Fierro et al., 2013). This study developed the following hypothesis to demonstrate the nature of the relationship between e-service recovery satisfaction and customer retention.

H4. There is a direct relationship between e-service recovery satisfaction and customer retention.

\subsection{Conceptual Framework}

Many studies have examined the relationships between loyalty, trust, satisfaction, prior experience and digital awareness, and the manner in which these factors affect customer satisfaction. The framework presented in this study is the result of an intensive literature review that revealed gaps in the existing literature. The study aims to prove the inter relationships among the five variables presented in Figure 1. The framework suggested that three customer determinants; accumulative trust, customer perception of feedback, and digital commitment have direct relationship with customer retention in the e-context. McCole (2004) emphasised that long-term customerprovider relationships are the conclusions of a building process. These long-term relationships can be represented by the variable accumulative trust and digital commitment, as both reflect the well-established relationship of customers with the provider in online transactions. While many studies have demonstrated that conducting effective service recovery can generate long-term customer trust and loyalty (Chang \& Chang, 2010; Kian, 2011; Michel et al., 2009; Pizzutti \& Fernandes, 2010; Quin et al., 2012; Wang et al., 2011). The study also investigates the relationship between e-service recovery satisfaction and customer retention in e-context. The airline industry in Malaysia is the context of the study. The sample unit is Malaysian passengers using the local airlines which in general had faced service failure. As such, this study developed a conceptual framework that is represented by Hypothesis H5:

H5. The customer factors accumulative trust, customer perception of feedback, and digital commitment affect customer retention when e-service recovery satisfaction acts as a mediating variable.

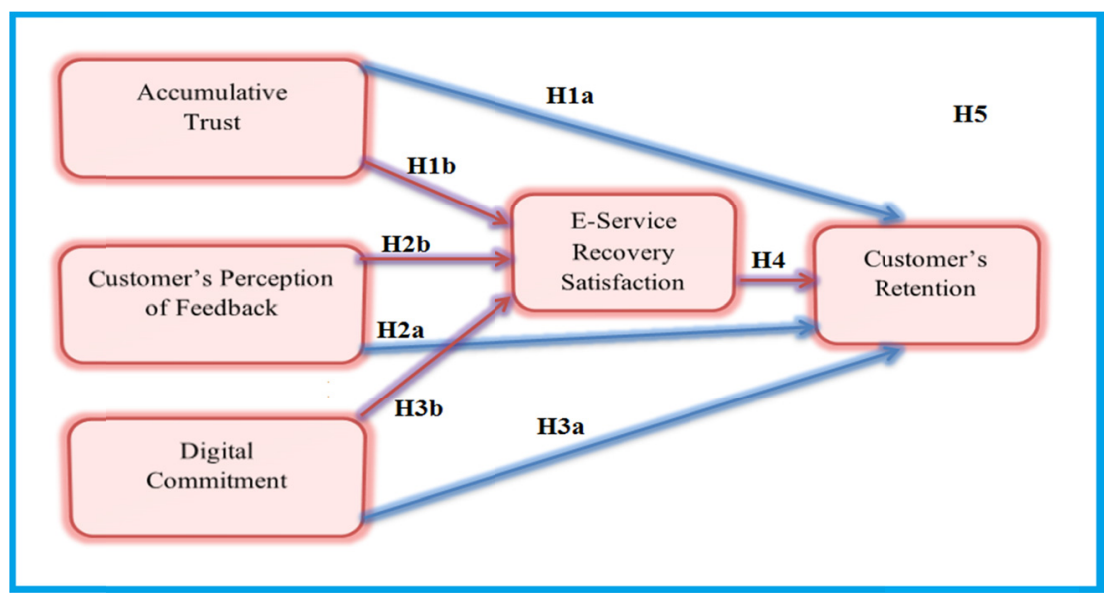

Figure 1. Study conceptual framework

\section{Methodology}

This study adopted quantitative approach to examine the relationships expressed in the hypotheses. A self-administrated questionnaire was utilised as the measurement instrument. In an attempt to purify the 
questionnaire, guarantee that all questions were clear to average respondents, and gain valuable feedback for the relevant items, pre-test and pilot tests were conducted. The questionnaire was in two languages, English and Bahasa Malay. A five-item Likert scale was used for all measures (Sekaran, 2013). Purposive random sampling or judgment sampling (Zikmund, 2012) was used to fulfil the study's objectives. The respondents were Malaysian passengers who used Malaysian Airlines and had experienced a service failure. Seven hundred questionnaires were distributed and 432 questionnaires were collected. The final number of usable questionnaires was 300. Structural equation modelling (SEM) was performed by utilising software analysis through the Statistical Package for the Social Sciences (SPSS) 22.0 and the Analysis Moment of Structures (AMOS) package version 22.0 (Byrne, 2013; Sentosa \& Mat, 2012). SEM and Confirmatory Factor Analysis (CFA) were conducted for data analysis to test and confirm interrelation among the constructs posited by the conceptual framework and to ensure goodness of fit to the conceptual model (Boshoff, 2014; Iacobucci et al., 2007; Sentosa \& Mat, 2012).

\section{Findings}

\subsection{Respondent Profiles}

Table 1 presents the 14 demographic categories that were examined. The first six examined the factors of gender, age, education level, number of travelling years, preferable airlines and salary. The remaining eight categories focused on respondent perceptions of the online context. The first six categories yielded the following results. Fifty-three per cent of respondents were male; 29.6 per cent were in the 41-50 years age group; the highest category in education was for diploma/bachelor holders, who comprised 37.0 per cent of respondents; and the highest category for travelling years was 40.3 per cent who had seven years or more of travelling experience. Moreover, 67.7 per cent selected that they did have a favourite airline. For the salary item, the highest rate was 46.0 per cent with a salary of RM 10.000 or above.

The second section of demographic categories was aimed at exploring the perceptions of Malaysian passengers regarding the e-context. For e-security perception, 40.6 per cent of respondents selected 'very high'. For number of e-purchases performed, 39.0 per cent reported more than 10 times (the highest rate in this category), clearly indicating that Malaysian customers have a high tendency for online purchasing. The most popular device used to perform an e-purchase was a personal computer ( 43.7 per cent), followed by smart phones (26.7 per cent). Perception of friendly or complicated provider websites scored 47.0 per cent for friendly websites, 21.3 per cent for complicated websites. System response category scored the highest rating in 'immediately' at 38.7 per cent. In addition, the highest rating for the number of e-complaints was 39.0 per cent for fewer than three times. For the item relating to the duration to perform e-service recovery, 55.3 per cent responded 'fast', 32.0 per cent responded 'reasonable' and 12.7 per cent responded 'slow'. The degree of satisfaction with e-service recovery was 56.0 per cent responding 'very satisfied', 38.3 per cent 'satisfied' and 5.7 per cent 'not satisfied'. In general, these figures demonstrate that Malaysia Airlines customers have a high tendency to use the internet, perform various online transactions and have high acceptance and exposure to the internet.

Table 1. Demographic profiles

\begin{tabular}{|c|c|c|c|c|c|}
\hline Category & Frequency & $\%$ & Category & Frequency & $\%$ \\
\hline 1. Gender & & & 8. E-purchase & & \\
\hline - $\quad$ Male & 159 & 53.0 & - $\quad>3$ times & 27 & 9.9 \\
\hline \multirow[t]{3}{*}{ Female } & 141 & 47.0 & 3-6 times & 67 & 22.3 \\
\hline & & & - $\quad 7-10$ times & 89 & 29.7 \\
\hline & & & - $\quad>10$ times & 117 & 39.0 \\
\hline 2. Age & & & 9. Device & & \\
\hline - $\quad 21-30$ years & 74 & 24.7 & - $\quad \mathrm{PC}$ & 131 & 43.7 \\
\hline $31-40$ years & 84 & 28.0 & Smart Phone & 80 & 26.7 \\
\hline $41-50$ years & 89 & 29.7 & Tablet & 73 & 24.3 \\
\hline $51-60$ years & 53 & 17.7 & Others & 16 & 5.3 \\
\hline 3. Education & & & 10. Website & & \\
\hline - $\quad$ Diploma/ Degree & 111 & 37.0 & - $\quad$ Friendly & 141 & 47.0 \\
\hline - $\quad$ Masters & 92 & 30.6 & Not friendly & 95 & 31.7 \\
\hline $\mathrm{PhD}$ & 65 & 21.7 & Complicated & 64 & 21.3 \\
\hline Others & 32 & 10.7 & & & \\
\hline
\end{tabular}




\begin{tabular}{|c|c|c|c|c|c|c|c|}
\hline \multicolumn{4}{|c|}{ 4. Years of Travelling } & \multicolumn{4}{|c|}{ 11. System response } \\
\hline$\bullet$ & $>3$ years & 60 & 20.0 & $\bullet$ & Immediately & 116 & 38.7 \\
\hline$\bullet$ & $3-6$ years & 119 & 39.7 & $\bullet$ & Less than 12 hours & 90 & 30.0 \\
\hline \multirow[t]{2}{*}{$\bullet$} & 7 years and above & 121 & 40.3 & $\bullet$ & $12-24$ hours & 30 & 10.0 \\
\hline & & & & & More than one day & 64 & 21.3 \\
\hline \multicolumn{4}{|c|}{ 5. Preferable Airlines } & \multicolumn{4}{|c|}{ 12. No. of E-complains } \\
\hline$\bullet$ & Yes & 203 & 67.7 & $\bullet$ & $<3$ & 117 & 39.0 \\
\hline \multirow[t]{2}{*}{$\bullet$} & No & 97 & 32.3 & $\bullet$ & $4-10$ & 82 & 27.3 \\
\hline & & & & & Never & 101 & 33.7 \\
\hline \multicolumn{4}{|c|}{ 6. Salary } & \multicolumn{4}{|c|}{ 13. E-Service Recovery Time } \\
\hline$\bullet$ & Less than RM 2000 & 38 & 12.7 & $\bullet$ & Fast & 166 & 55.3 \\
\hline$\bullet$ & RM 2000-6000 & 50 & 16.7 & $\bullet$ & Reasonable & 96 & 32.0 \\
\hline$\bullet$ & RM 6000-10,000 & 74 & 24.7 & $\bullet$ & Slow & 38 & 12.7 \\
\hline$\bullet$ & $>$ RM 10,000 & 138 & 46.0 & & & & \\
\hline \multicolumn{4}{|c|}{ 7. E-Security } & \multicolumn{4}{|c|}{ 14. E-service Recovery Satisfaction } \\
\hline$\bullet$ & Very high & 122 & 40.7 & $\bullet$ & Very satisfied & 168 & 56.0 \\
\hline$\bullet$ & Moderate & 104 & 34.7 & $\bullet$ & Satisfied & 115 & 38.4 \\
\hline$\bullet$ & Low & 74 & 24.7 & $\bullet$ & Not satisfied & 16 & 5.4 \\
\hline
\end{tabular}

\subsection{Analysis of Findings}

The survey achieved a good response rate of 42.85 per cent, which was higher than the researchers' expectations (of 30-40 per cent) (Hair et al., 2010). The reliability test represented by Cronbach's Alpha measures demonstrated that the following variables had a high reliability (the accepted value is 0.7) (Byrne, 2013). The dependent variable, customer retention, scored high internal consistency of 0.898 , while the independent variables scored as follows: accumulative trust, 0.980; customer perception of feedback, 0.830; and digital commitment, 0.955 which also indicate high reliability. The mediating variable, e-service recovery satisfaction scored 0.734 demonstrating good reliability.

Table 2. Regression weights for hypothesis relations

\begin{tabular}{|c|c|c|c|c|c|c|}
\hline Hypothesis & & Estimate & St. Error & $\mathrm{CR}$ & P-value & Result \\
\hline H1a RETENTION & <---ACC. TRUST & 0.053 & 0.058 & 0.834 & 0.404 & Non-significant \\
\hline H2a RETENTION & <---FEEDBACK & 0.801 & 0.227 & 5.661 & 0.005 & Significant \\
\hline H3a RETENTION & <---COMMITMENT & 0.039 & 0.066 & 0.632 & 0.528 & Non-significant \\
\hline H4 RETENTION & $<---E-S R S$ & 0.137 & 0.108 & 1.909 & 0.056 & Significant \\
\hline H1b E-SRS & $<---A C C$. TRUST & 0.172 & 0.048 & 2.178 & 0.029 & Significant \\
\hline $\mathrm{H} 2 \mathrm{~b}$ E-SRS & $<---F E E D B A C K$ & 0.364 & 0.120 & 0.223 & 0.001 & Non-significant \\
\hline H3b E-SRS & <---COMMITMENT & 0.240 & 0.057 & 2.982 & 0.003 & Significant \\
\hline
\end{tabular}

Note. E-SRS = e-service recovery satisfaction; ACC. TRUST = accumulated trust.

Table 2 outlines the hypothesised relations among the variables. The measurement readings supported hypothesis $\mathrm{H} 1 \mathrm{~b}(\mathrm{CR}: 2.178, \mathrm{P}<0.05)$, which indicates that e-service recovery does have a mediating role in the relation between accumulative trust and customer retention. Hypothesis H1a was not supported (CR: 0.834, $\mathrm{P}>0.05$ ), which indicates that accumulative trust has no direct relationship with customer retention. Hypothesis $\mathrm{H} 2 \mathrm{~b}$ was not supported (CR: $0.223, p>0.001)$, indicating that e-service recovery has no significant role in the relationship between customer perception of feedback and customer retention. However, H2a was asserted (CR: 5.661, $p<0.05$ ), supporting the hypothesis that customer perception of feedback has a direct relationship with customer retention. Hypothesis $\mathrm{H} 3 \mathrm{~b}$ was also asserted (CR: 2.982, $p=0.003$ ), demonstrating that e-service recovery does have a mediating role in the relation between digital commitment and customer retention. Hypothesis H3a was not supported (CR: 0.632, $p>0.05$ ), indicating that there is no direct relationship between digital commitment and customer retention. Hypothesis $\mathrm{H} 4$ was asserted (CR: 1.909, $p=0.05$ ), indicating that e-service recovery satisfaction is positively related to customer retention. Hypothesis $\mathrm{H} 5$ relates to the research conceptual framework, and the interrelationships among the five variables were proven. 


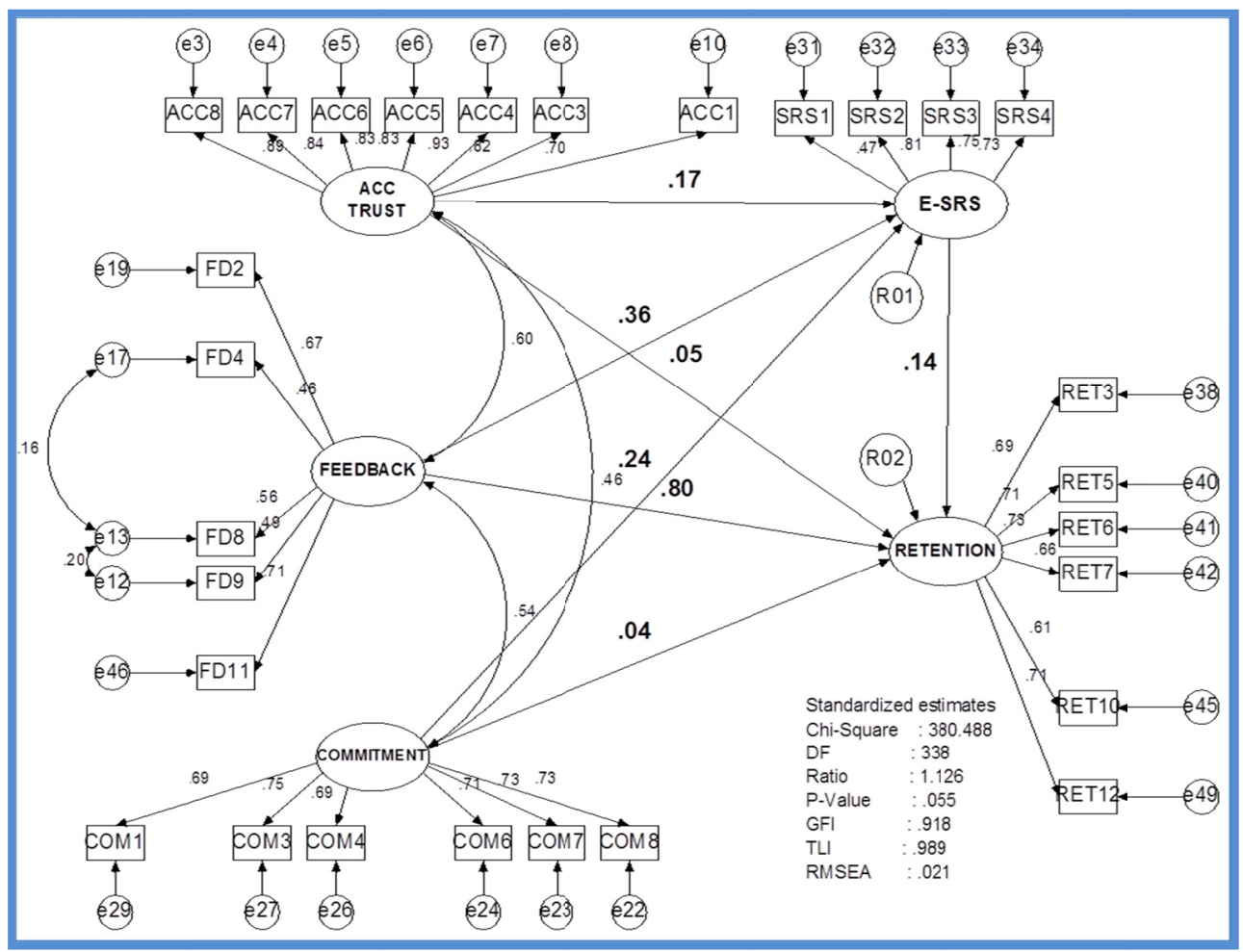

Figure 2. Re-specified model

Figure 2 represents the re-specified model. The significance of the goodness-of-fit indices confirmed the significant loadings of the measurements. The re-specified model demonstrates the low level of common and unique error, and presents the interaction among predictors of the endogenous and exogenous variables. The goodness-of-fit indices for the 47 observed variables of the five main variables demonstrate the acceptance level (significance $>0.5$ ), the significance of loadings ranged from 0.512 to 0.848 . The factor loadings or regression estimates of latent observed variables are all above 0.50. The re-specified model presented in Figure 2 also demonstrates that the model has a substantial portion of the variance in all of the endogenous and exogenous variables (square multiple correlations). In addition, the model presents the standardised path coefficients and their significance level on causal paths.

In conclusion, Figure 3 represents the final empirical model for the current study. The model demonstrates clearly that e-service recovery satisfaction has a significant mediating role in the relation between accumulative trust and customer retention; and between digital commitment and customer retention in the e-context. The third factor, customer perception of feedback, has a significant direct relationship with customer retention. The model also demonstrates that there is a significant positive influential relationship between e-service recovery satisfaction and customer retention. 


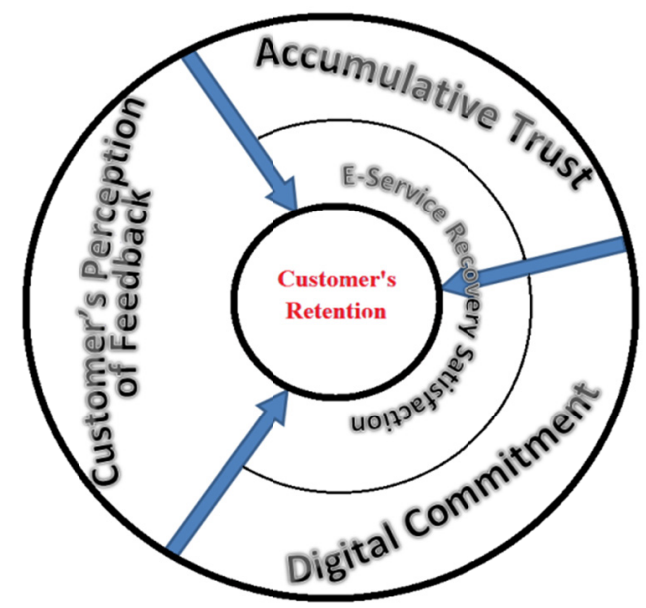

Figure 3. Empirical model developed by current study

\section{Conclusions and Recommendations}

The online environment and digital era are interesting areas in which to conduct more research. These areas are witnessing continual growth that leads to new challenges for service providers. As such, the need to identify those challenges, especially those concerning retaining existing customers becomes more urgent. The current study has made two significant contributions to the literature and industry. The contributions to literature are as follows. First, the study presented two new concepts (accumulative trust and digital commitment) that fit the online context, which were conceptualised after conducting an intensive analysis of the existing literature. Second, this study has proven that both accumulative trust and digital commitment have a significant effect on customer retention when high e-service recovery satisfaction is achieved. Third, this study demonstrated that customer perception of feedback has a direct influence on customer retention. Fourth, it was demonstrated that satisfaction with e-service recovery has a direct influence on customer retention.

For industry, the findings emphasised the importance of recovery approaches that providers offer in the e-context. Achieving satisfaction with recovery leads to higher levels of customer loyalty and commitment. In addition, satisfied and loyal customers expand their purchase items to include other products provided by the same provider. It will also lead to spreading positive word-of-mouth. As such, these customers will act as free promoters for the provider. The findings should urge businesses to employ e-service recovery strategies in a manner that leads to maximum customer satisfaction. E-service recovery satisfaction is a critical, effective and powerful tool in retaining customers, attracting new customers and guaranteeing a long-term customer-provider relationship. These strategies lead to cost decreases and revenue increases, which result in profit increase in the long term.

Future research should aim at enrich the topic of e-service recovery satisfaction by exploring the following themes: (1) industry perception of e-service recovery and the level of satisfaction the current recovery strategies have achieved; (2) the mechanisms that the management can use to estimate and evaluate e-service recovery satisfaction; and (3) how providers can evaluate service failure and implement convenient and efficient recovery strategies to manage frustrated customers and ensure they become satisfied customers that are retained by the business. In addition, future studies could consider testing the study empirical model with other industries. Also scholars can duplicate the current study by employing qualitative methodology to provide more in-depth information.

\section{References}

Adebiyi, S. O., \& Adeola, M. M. (2014). Service Quality, Perceived Value and Customer Satisfaction as determinant of Airline choice in Nigeria. International Letters of Social and Humanistic Sciences, 20(9), 66-80. http://dx.doi.org/10.18052/www.scipress.com/ILSHS.20.66

Al-Jader, R. A., \& Sentosa, I. (2015a). A Conceptual Development on the Mediating Role of E-Service Recovery on the Relationship Between Customer Determinants and Customer Retention in the Airline Industry in Malaysia (A Structural Equation Modeling Approach). Indian Journal of Commerce \& $\begin{array}{lllll}\text { Management } & \text { Studies. } & 4(1), & 103-108 . & \text { Retrieved }\end{array}$ 
http://www.scholarshub.net/ijcms/vol6/issue1/Paper_14.pdf

Al-Jader, R. A., \& Sentosa, I. (2015b). An Emperical Study on the Mediating Effect of E-Service Recovery Satisfaction on the Achievement of Customer Retention in the Airline Industry in Malaysia. Journal of Business and Management (IOSR-JBM). 17(1), 42-49. Retrieved from http://iosrjournals.org/iosr-jbm/papers/Vol17-issue1/Version-2/G017124249.pdf

Allagui, A., \& Temessek, A. (2005). Loyalty toward web portal: proposition and empirical testing of an integrative model. In Proceedings of the 21st International Conference of AFM, Bordeaux, France, May ( $\mathrm{p}$. 6). Arokiasamy, A. R. A. (2014). Service Quality on Customer Loyalty and Intentions to Switch in the Airline Industry in Malaysia. Australian Journal of Basic and Applied Sciences, 8(6), 279-284. Retrieved from http://www.ajbasweb.com/old/ajbas/2014/April/279-284-april14.pdf

Bailey, D. (1994). Recovery from customer service shortfalls. Managing Service Quality, 4(6), 25-28.

Bart, Y., Shankar, V., Sultan, F., \& Urban, G. L. (2005). Are the drivers and role of online trust the same for all web sites and consumers? A large-scale exploratory empirical study. Journal of marketing, 69(4), 133-152. Retrieved from http://ebusiness.mit.edu/urban/papers/are\%20the\%20drivers\%20and\%20role\%20\%28jppm\%202005\%29.p df

Bashar, A., \& Wasiq, M. (2013). E-satisfaction and E-loyalty of Consumers Shopping Online. Global Sci- Tech, 5(1), 6-19. Retrieved from https://www.academia.edu/2968801/Online_Shopping_and_Consumer_Behaviour_Esatisfaction_and_E-loyalty_of_Consumers_Shopping_Online

Bataineh, A. Q., Al-Abdallah , G. M., Salhab, G. M., \& Shoter, A. M. (2015). The Effect of Relationship Marketing on Customer Retention in the Jordanian's Pharmaceutical Sector. International Journal of Business and management, 10(3), 117-131. http://dx.doi.org/10.5539/ijbm.v10n3p117

Berry, L. L., \& Parasuraman, A. (2004). Marketing services: Competing through quality. Simon and Schuster.

Bijmolt, T. H. A., Huizingh, E. K. R. E., \& Krawczyk, A. (2014). Effects of complaint behaviour and service recovery satisfaction on consumer intentions to repurchase on the internet. Internet Research, 24(5), 608-628. http://dx.doi.org/10.1108/IntR-03-2012-0056

Bitner, M. J., Booms, B. H., \& Tetreault, M. S. (1990). The service encounter: Diagnosing favorable and unfavorable incidents. Journal of Marketing, 54(1), 71. Retrieved from http://www.ida.liu.se/ steho87/und/htdd01/9602131056.pdf

Boshoff, C. (1997). An experimental study of service recovery options. International Journal of Service Industry Management, 8(2), 110-130. http://dx.doi.org/10.1108/09564239710166245

Boshoff, C. (2014). The influence of' buffering variables on clients' willingness to engage in retribution behaviour after a service failure. South African Journal of Economic and Management Sciences, 17(3), 297-309. Retrieved http://www.scielo.org.za/scielo.php?pid=S2222-34362014000300005\&script=sci_arttext

Broderick, A. J., \& Vachirapornpuk, S. (2002). Service quality in internet banking: the importance of customer role. Marketing Intelligence \& Planning, 20(6), 327-335.

Byrne, B. M. (2013). Structural equation modeling with AMOS: Basic concepts, applications, and programming. Routledge.

Cambra Fierro, J., Melero Polo, I., \& Sesé Oliván, F. J. (2013). From dissatisfied customers to evangelists of the firm: A study of the Spanish mobile service sector. http://dx.doi.org/10.1016/j.cede.2013.10.001

Carter, M., Wright, R., Thatcher, J. B., \& Klein, R. (2014). Understanding online customers' ties to merchants: the moderating influence of trust on the relationship between switching costs and e-loyalty. European Journal of Information Systems, 23(2), 185-204. http://dx.doi.org/10.1057/ejis.2012.55

Cegarra-Navarro, J. G., Eldridge, S., Martinez-Caro, E., Teresa, M., \& Polo, S. (2014). The Value of Extended Framework of TAM in the Electronic Government services. Electronic Journal of Knowledge Management, 12(1). Retrieved from http://www.ejkm.com/volume12/issue1/p14

Chang, W. L., \& Chang, H. C. (2011). A Dynamic System of E-Service Failure, Recovery and Trust. Retrieved from http://aisel.aisnet.org/pacis2011/39/ 
Chang, Y. W., \& Chang, Y. H. (2010). Does service recovery affect satisfaction and customer loyalty? An empirical study of airline services. Journal of Air Transport Management, 16(6), 340-342. http://dx.doi.org/10.1016/j.jairtraman.2010.05.001

Chen, Z., \& Dubinsky, A. J. (2003). A conceptual model of perceived customer value in e - commerce: A preliminary investigation. Psychology \& Marketing, 20(4), 323-347. http://dx.doi.org/10.1002/mar.10076

Chiu, C. Y., Lin, Z. P., Chen, P. C., \& Kuo, I. T. (2009). Applying RFM Model to Evaluate the E-loyalty for Information-based Website. International Journal of Electronic Business Management, 7(4), 278-285. Retrieved from http://ijebm.ie.nthu.edu.tw/IJEBM_Web/IJEBM_static/Paper-V7_N4/A06.pdf

Craighead, C. W., Karwan, K. R., \& Miller, J. L. (2004). The effects of severity of failure and customer loyalty on service recovery strategies. Production and Operations Management, 13(4), 307-321. http://dx.doi.org/10.1111/j.1937-5956.2004.tb00220.x

Creswell, J. (2013). Research design, qualitative, quantitative, and mixed methods approaches. Sage. USA.

Davis, F. D., Bagozzi, R. P., \& Warshaw, P. R. (1989). User acceptance of computer technology: a comparison of two theoretical models. Management science, 35(8), 982-1003. http://dx.doi.org/10.1287/mnsc.35.8.982

De Mooij, M. (Ed.). (2010). Consumer behavior and culture: Consequences for global marketing and advertising. Sage Publications.

Edvardsson, B., Tronvoll, B., \& Gruber, T. (2011). Expanding understanding of service exchange and value cocreation: a social construction approach. Journal of the Academy. http://dx.doi.org/10.1007/s11747-010-0200-y

Eid, M. I. (2011). Determinants of e-commerce customer satisfaction, trust, and loyalty in Saudi Arabia. Journal of Electronic Commerce Research, 12(1), 78-93. Retrieved from http://web.csulb.edu/journals/jecr/issues/20111/index.pdf

Eisingerich, A. B., Auh, S., \& Merlo, O. (2014). Acta Non Verba? The Role of Customer Participation and Word of Mouth in the Relationship Between Service Firms' Customer Satisfaction and Sales Performance. Journal of Service Research, 17(1), 40-53. Retrieved from http://jsr.sagepub.com/content/early/2013/05/30/1094670513490836

Ennew, C. T., Binks, M. R., \& Chiplin, B. (2015). Customer Satisfaction and Customer Retention: An Examination of Small Businesses and Their Banks in the UK. In Proceedings of the 1994 Academy of Marketing Science (AMS) Annual Conference (pp. 188-192). Springer International Publishing. Journal of

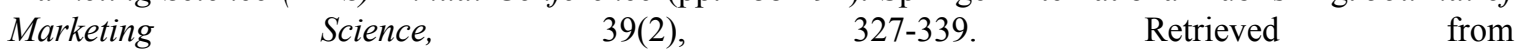
http://link.springer.com/chapter/10.1007/978-3-319-13162-7_49

Flavián, C., \& Guinalíu, M. (2006). Consumer trust, perceived security and privacy policy: three basic elements of loyalty to a web site. Industrial Management \& Data Systems, 106(5), 601-620. http://dx.doi.org/10.1108/02635570610666403

Forgas, S., Palau, R., Sánchez, J., \& Huertas-García, R. (2012). Online drivers and offline influences related to loyalty to airline websites. Journal of Air Transport Management, 18(1), 43-46. http://dx.doi.org/10.1016/j.jairtraman.2011.08.003

Gupta, S., Lehmann, D. R., \& Stuart, J. A. (2004).Valuing customers. Journal of marketing research, 41(1), 7-18. Retrieved from https://www0.gsb.columbia.edu/mygsb/faculty/research/pubfiles/534/Valuing_Customers-JMR_2003.pdf

Ha, H., \& Akamavi, R. (2009). Does Trust Really Matter in Electronic Shopping? A Comparison Study of Korean, Taiwanese, and UK Consumers. Seoul Journal of Business, 15(1). Retrieved from http://hdl.handle.net/10371/32114

Hair JR., J. F., Black, W. C., Babin, B. J., \& Anderson, R. E. (2010). Multivariate Data Analysis (7th ed.). Upper Saddle River: Auflage. $\quad$ Retrieved from http://icplus.org/uploads/Multivariate_Data_Analysis_7th_Edition.pdf

Hansemark, O. C., \& Albinson, M. (2004). Customer satisfaction and retention: The experiences of individual employees. Managing Service Quality, 14(1), 40-57. http://dx.doi.org/10.1108/09604520410513668

Hess, R. J., Jr., Ganesan, S., \& Klein, N. M. (2003). Service failure and recovery: The impact of relationship factors on customer satisfaction. Academy of the Academy of Marketing Science, 31(2), 127-145. Retrieved from $\mathrm{http}: / /$ jam.sagepub.com/content/31/2/127 
Hoffman, D. L., \& Novak, T. P. (2009). Flow online: lessons learned and future prospects. Journal of Interactive Marketing, 23(1), 23-34. http://dx.doi.org/10.1016/j.intmar.2008.10.003

Hoffman, K. D., Kelley, S. W., \& Chung, B. C. (2003). A CIT investigation of service scape failures and associated recovery strategies. Journal of Services Marketing, 17(4), 322-340. http://dx.doi.org/10.1108/08876040310482757

Holloway, B. B., Wang, S., \& Parish, J. T. (2005).The role of cumulative online purchasing experience in service recovery management. Journal of Interactive Marketing, 19(3), 54-66. http://dx.doi.org/10.1002/dir.20043

Hsieh, M. T., \& Tsao, W. C. (2014). Reducing perceived online shopping risk to enhance loyalty: a website quality perspective. Journal of Risk Research, 17(2), 241-261. http://dx.doi.org/10.1080/13669877.2013.794152

Iacobucci, D., Saldanha, N. \& Deng, JX. (2007). A meditation on mediation: Evidence that structural equations models perform better than regressions. Journal of Consumer Psychology, 17(2), 140-154. Retrieved from http://resource.owen.vanderbilt.edu/facultyadmin/data/research/2383full.pdf

Internet World Stats. (2014). Retrieved from http://www.internetworldstats.com/stats.htm

Jarvenpaa, S. L., Tractinsky, N., \& Saarinen, L. (1999). Consumer trust in an internet store: a cross - cultural validation. Journal of Computer - Mediated Communication, 5(2), 0-0. http://dx.doi.org/10.1111/j.1083-6101.1999.tb00337.x

Kau, A., \& Loh, E. (2006). The effects of service recovery on consumer satisfaction: A comparison between complainants and non-complainants. Journal of Services Marketing, 20(2), 101-103. http://dx.doi.org/10.1108/08876040610657039

Kerin, R., Hartley, S. \& Rudelius, W. (2009). Marketing (9th ed.). McGraw-Hill/ Irwin, USA.

Kian, T. P. (2011). A Model for Measuring the Relationship between Service Recovery and Service Quality: A Case Study at the Public University Library. In 2nd International Conference on Business and Economic Research (2nd ICBER 2011) Proceeding. Conference Master Resources. Retrieved from http://core.ac.uk/download/pdf/6405415.pdf

Kim, J., Jin, B. \& Swinney, J. (2008). The role of e-tail quality, e-satisfaction and e-trust in online loyalty development process. Journal of Retailing and Consumer Services. http://dx.doi.org/10.1016/j.jretconser.2008.11.019

Kim, K., \& Prabhakar, B. (2000). Initial trust, perceived risk, and the adoption of internet banking. In Proceedings of the twenty first international conference on Information systems (pp. 537-543). Association for Information Systems.

Kotler, P., \& Keller, K. L. (2006). Marketing Management (12th ed.). Upper Saddle River, NJ: Prentice Hall.

Liao, N. N. H., \& Wu, T. C. (2009). The pivotal role of trust in customer loyalty: empirical research on the system integration market in Taiwan. The Business Review, 12(2), 277-282.

Mangold, W., Miller, G., \& Brockway, G. (1999). Word-of-Mouth Communication in the Service Marketpalce. Journal of Service Marketing, 13(1), 73-90. http://dx.doi.org/10.1108/08876049910256186

Manusov, V., \& Spitzberg, B. (2008). Attribution theory. Chapter 3.

Mattila, A. S., \& Cranage, D. (2005). The impact of choice on fairness in the context of service recovery. Journal of Service Marketing, 19(5), 271-279.

McCole, P. (2004). Dealing with complaints in services. International Journal of Contemporary Hospitality Management, 16(6), 345-354.

McCollough, M. A. (2009). The recovery paradox: The effect of recovery performance and service failure on post-recovery customer satisfaction. Academy of Marketing Studies Journal, 13(1). Retrieved from http://www.freepatentsonline.com/article/Academy-Marketing-Studies-Journal/219063769.html

Michel, S., Bowen, D., \& Johnston, R. (2009). Why service recovery fails: tensions among customer, employee, and process perspectives. Journal of Service Management, 20(3), 253-273. Retrieved from http://dx.doi.org/10.1108/09564230910964381

Ogungbure, A. (2009). An attributional approach to the formation of recovery expectation in the internet-based service encounters after service failure and recovery. $\mathrm{PhD}$ thesis. Nova Southeastern University. 
Ok, C. (2004). The effectiveness of service recovery and its role in building long-term relationships with customers in a restaurant setting. (Doctoral dissertation, Kansas State University). Retrieved from https://krex.k-state.edu/dspace/bitstream/handle/2097/31/ChihyungOk.pdf?sequence=1

Oliver, R. L. (1980). A cognitive model of the antecedents and consequences of satisfaction decisions. Journal of marketing research, 460-469. http://dx.doi.org/10.2307/3150499

Oliver, R. L. (1997). Satisfaction: A behavioural perspective on the consumer. Boston, MA: McGraw-Hill.

Oliver, R. L. (1999). Whence Consumer Loyalty? Journal of Marketing, 63(Special Issue), 33-44. Retrieved from http://www.uta.edu/faculty/richarme/MARK\%205342/Articles/Oliver\%201999.pdf

Parasuraman, A., Zeithaml, V. A., \& Malhotra, A. (2005). A multiple-item scale for assessing electronic service quality. Journal of Service Research, 7(3), 213-233. http://dx.doi.org/10.1177/1094670504271156

Pizzutti, C., \& Fernandes, D. (2010). Effect of recovery efforts on consumer trust and loyalty in E-tail: A contingency model. International Journal of Electronic Commerce, 14(4), 127-160. http://dx.doi.org/10.2753/JEC1086-4415140405

Quin, J., Chen, Q., \& Wan, Y. (2012). The Effects of Service Recovery Justice and Perceived Switching Costs on Customer Loyalty in E-tailing. POMS 23rd Annual Conference Chicago, Illinois, USA. Retrieved from http://www.pomsmeetings.org/confproceedings/025/FullPapers/FullPaper_files/025-1295.pdf

Rachjaibun, N. (2007). A study of antecedents of e-relationship quality in hotel websites. $\mathrm{PhD}$ thesis. University of Oklahoma. USA. Retrieved from http://digital.library.okstate.edu/etd/umi-okstate-2275.pdf

Reichheld, F. F., \& Sasser, Jr., W. E. (1990). Zero defections. Quality comes to services. Harvard Business Review, 68(5), 105-111.

Rondeau, K. V. (1994). Getting a second chance to make a first impression. Medical Laboratory Observer, 1(26), $22-25$.

Santos, J., \& Boote, J. (2003). A theoretical exploration and model of consumer expectations, post - purchase affective states and affective behaviour. Journal of Consumer Behaviour, 3(2), 142-156. http://dx.doi.org/10.1002/cb.129

Sekaran, U. (2013). Research methods for business, a skill building approach (4th ed.). Wiley \& Sons.

Sentosa, I., \& Mat, N. K. (2012). Examining a theory of planned behavior (TPB) and Technology acceptance model (TAM) in Internet purchasing using structural equation Modeling. Journal of Arts, Science \& Commerce, 3(2), 62-77.

Severt, D. E. (2002). The customer's path to loyalty: a partial test of the relationships of prior experience, justice, and customer satisfaction (Doctoral dissertation, Virginia Polytechnic Institute and State University).

Shankar, V., Smith, A., \& Rangaswamy, A. (2003). Customer satisfaction and loyalty in online and offline environments. International Journal of Research in Marketing, 20(2), 153-175. http://dx.doi.org/10.1016/S0167-8116(03)00016-8

Shukla, P. (2014). The impact of organizational efforts on consumer concerns in an online context. Information \& Management, 51(1), 113-119. http://dx.doi.org/10.1016/j.im.2013.11.003

Smith, A. K., Bolton, R. N., \& Wagner, J. (1999). A model of customer satisfaction with service encounters involving failure and recovery. Journal of marketing research, 356- 372. http://dx.doi.org/10.1.1.410.6871.

Söderlund, M. (1998). Customer satisfaction and its consequences on customer behaviour revisited: The impact of different levels of satisfaction on word-of-mouth, feedback to the supplier and loyalty. International Journal of Service Industry Management, 9(2), 169-188. http://dx.doi.org/10.1108/09564239810210532

Sousa, R., \& Voss, C. A. (2009). The effects of service failures and recovery on customer loyalty in e-services: An empirical investigation. International Journal of Operations \& Production Management, 29(8), 834-864. http://dx.doi.org/10.1108/01443570910977715

St-James, Y., \& Taylor, Sh. (2004). Delight-as-magic: Refining the conceptual domain of customer delight. Advances in Consumer Research, 31. Retrieved from http://acrwebsite.org/volumes/9008/volumes/v31/NA-31

Tarokh, M. J., \& Ghahremanloo, H. (2007). Intelligence CRM: a contact center model. Service Operations and Logistics, and Informatics, SOLI 2007. IEEE International Conference on (pp. 1-6). 
http://dx.doi.org/10.1109/SOLI.2007.4383914

Tax, S. S., Brown, S. W., \& Chandrashekaran, M. (1998). Customer evaluations of service complaint experiences: implications for relationship marketing. The Journal of Marketing, 60-76.

Tsai, C. C., Yang, Y. K., \& Cheng, Y. C. (2014). Does relationship matter? Customers' response to service failure. Managing Service Quality, 24(2), 139-159. http://dx.doi.org/10.1108/MSQ-06-2013-0113

Velmurugan, M. S., \& Velmurugan, M. S. (2014). Consumers' Awareness, Perceived Ease of Use toward Information Technology Adoption in 3G Mobile Phones' Usages in India. Asian Journal of Marketing, 8(1). http://dx.doi.org/10.3923/ajm.2014.1.23

Voss, C. A. (2003). Rethinking paradigms of service: Service in a virtual environment. International Journal of Operations \& Production Management, 23(1), 88-104. http://dx.doi.org/10.1108/01443570310453271

Wang, F., \& Ferrari, P. A. (2014). Multidimensional item response theory models for dichotomous data in customer satisfaction evaluation. Journal of Applied Statistics, 1-12. http://dx.doi.org/10.1080/02664763.2014.907395

Wang, K. Y., Hsu, L. C., \& Chih, W. H. (2014). Retaining customers after service failure recoveries: A contingency model. Managing Service Quality, 24(4), 318-338. http://dx.doi.org/10.1108/MSQ-11-20130251

Wang, Y. S., Wu, S. C., Lin, H. H., \& Wang, Y. Y. (2011). The relationship of service failure severity, service recovery justice and perceived switching costs with customer loyalty in the context of e- tailing. International Journal of Information Management, 31(4), 350-359. http://dx.doi.org/10.1016/j.ijinfomgt.2010.09.001

Yang, Z., \& Jun, M. (2002). Consumer perception of e-service quality: form purchaser and non-purchaser perspectives. Journal of Business Strategies, 19(1), 19-41. Retrieved from http://www.freepatentsonline.com/article/Journal-Business-Strategies/87206218.html

Yang, Z., \& Peterson, R. T. (2004). Customer perceived value, satisfaction, and loyalty: the role of switching costs. Psychology \& Marketing, 21(10), 799-822. http://dx.doi.org/10.1002/mar.20030

Yen, Ch., \& Lu, H. P. (2008). Effects of e-service quality on loyalty intention: an empirical study in online auction. Managing Service Quality, 18(2), 127-146. http://dx.doi.org/10.1108/09604520810859193

Zeithaml, V. A., Berry, L. L., \& Parasuraman, A. (1996). The behavioural consequences of service quality. Journal of Marketing, 60(2), 31-46. Retrieved from http://www.researchgate.net/profile/Valarie_Zeithaml/publication/248768479_The_Behavioral_Consequen ces_of_Service_Quality/links/543d1f660cf20af5cfbfacea.pdf

Zeithmal, V., Parasuraman, A., \& Malhotra, A. (2000). A conceptual framework for understanding e-service quality: Implications for future research and managerial practice. Working paper, report No. 00-115. Marketing Science Institute, Cambridge. MA. Retrieved from http://www.msi.org/reports/a-conceptual-framework-for- understanding-e-service-quality-implications-for/

Zemke, R. E., \& Connellan, T. (2001). E-Service: Twenty-four ways to keep your customers when the competition is just a click away. New York: American Management Association. Retrieved from https://catalog.wakegov.com/Record/605805

Zhou, Y., \& Amin, M. (2014). Factors Affecting Online Community Commitment in China: A Conceptual Framework. Journal of Technology Management in China, 9(1), 3. http://dx.doi.org/10.1108/JTMC-08-2013-0033

Zikmund, W. (2012). Business research methods (7th ed.). South Western Cengage Learning. USA.

\section{Copyrights}

Copyright for this article is retained by the author(s), with first publication rights granted to the journal.

This is an open-access article distributed under the terms and conditions of the Creative Commons Attribution license (http://creativecommons.org/licenses/by/3.0/). 